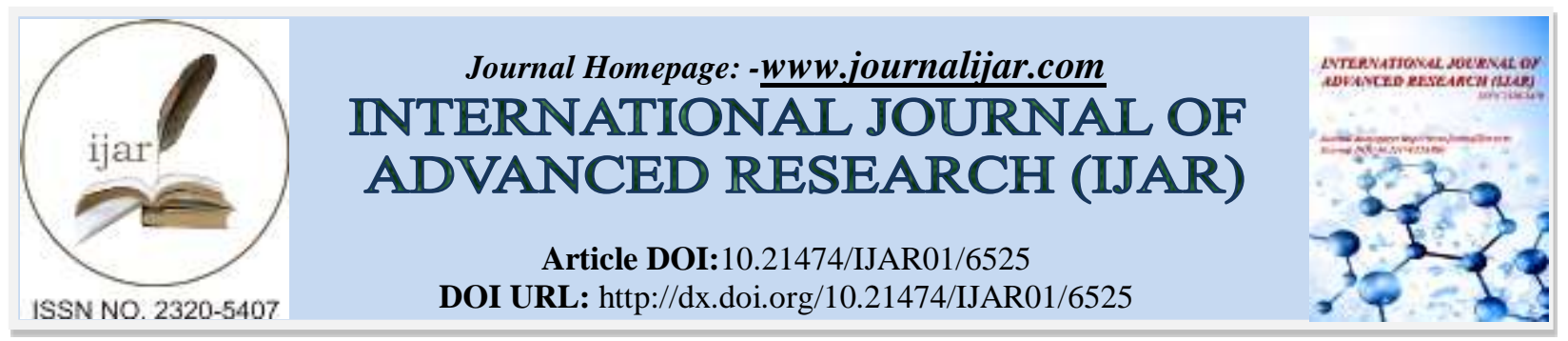

RESEARCH ARTICLE

\title{
MAXILLARY TALON CUSP IN PRIMARY LATERAL INCISOR - A CASE REPORT.
}

Dr. A. Vasanthakumari ${ }^{1}$, Dr. K.Vivek ${ }^{2}$, Dr. Vivek Reddy ${ }^{2}$, Dr. I. Jai Ganesh ${ }^{2}$ and Dr. S. Lokesh ${ }^{2}$.

1. Professor and Head, Department of Pedodontics, Adhiparasakthi Dental College \& Hospital, Melmaruvathur603319, India.

2. Senior Lecturers, Department of Pedodontics, Adhiparasakthi Dental College \& Hospital, Melmaruvathur603319, India.

\section{Manuscript Info}

Manuscript History

Received: 13 December 2017

Final Accepted: 15 January 2018

Published: February 2018

Keywords:-

Talon cusp, Primary incisors, Cingulum.

\section{Abstract}

Talon cusp is a rare developmental anomaly that occurs predominantly on palatal surface of maxillary incisors with varied prevalence in different populations. Its presence causes the problem in esthetics, prevention of caries and occlusal accommodation for the patient and problems in the diagnosis and clinical management for the dentist. This article reports a case of talon cusp on the palatal surface of the primary maxillary lateral incisor in a three year old girl patient.

Copy Right, IJAR, 2018,. All rights reserved.

\section{Introduction:-}

A talon cusp is a dental anomaly commonly occurring in the permanent dentition compared to the primary dentition and shows a predilection for maxilla over the mandible. It is a supernumerary structure projecting from the dentoenamel junction to a variable distance toward the incisal edge of an anterior incisor tooth. Mitchell first described this anomaly as a "process of horn like shape, curving from the base downwards to the cutting edge" on the lingual surface of a maxillary central incisor. Due to its resemblance to an eagle's talon it is named as talon cusp by Mellor and Ripa ${ }^{1}$.

The exact etiology is not known, but it is suggested to be a combination of genetic and environmental factors. It is thought to arise during the morphodifferentiation stage of tooth development, as a result of out folding of the enamel organ or hyper productivity of the dental lamina. ${ }^{2}$ It is also suggested that disturbances during morphodiffeentiation such as altered endocrine function might affect the shape and size of the tooth without impairing the function of ameloblasts and odontoblasts. The anomalous talon cusp in composed of normal enamel and dentin with varying extension of pulp tissue ${ }^{3}$.

With regard to tooth affinity only central incisors are involved in the primary dentition and the maxillary lateral incisor is most often affected in the permanent dentition (67\%) followed by central incisors (24\%) and canines ( $9 \%$ ) and the overall prevalence ranging from 0.66 to $7.7 \% .^{4}$ The total number of reported cases in the primary dentition worldwide is less and most of them are males. Very limited cases only reported from the Indian population. This article adds one more case to the existing pool of cases in primary dentition. ${ }^{5}$

\section{Case Report:-}

A three year old girl child belonging to the low socioeconomic group reported to the Department of Pedodontics for a routine dental check-up. The medical and familial history are non-contributory. The extraoral findings were not significant and intraoral findings revealed with well aligned intact primary dentition. A proximal talon cusp was 
visible on the palatal surface of the right maxillary primary lateral incisor. No other anterior tooth had this projection. Occlusion was normal and there was no interference on closure. The involved incisor on closer examination was found to be morphologically different from its antimere with a concavity present on the lateral surface corresponding to the projection on the palatal side giving it a pilled back appearance along with a sagged ' $U$ ' shaped incisal edge, an intraoral radiograph revealed the pulp horn extending to nearly half the length of the talon's cusp. No treatment was rendered apart from sealing the sides of the talon cusp with a fissure sealant.

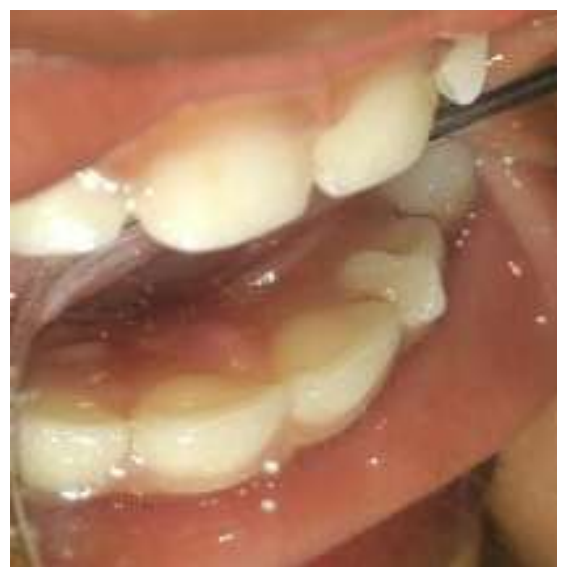

Fig - 1:- Talon cusp on the palatal surface of 52.

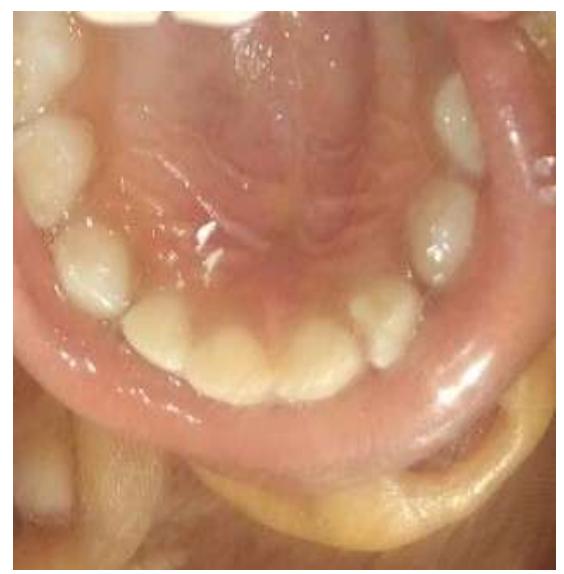

Fig - 2:- Talon cusp seen on the palatal surface of right maxillary primary lateral incisor.

\section{Discussion:-}

Talon cusp is defined as an additional cusp that predominantly projects from the lingual surface of primary or permanent anterior teeth is morphologically well delineated and extends at least half the distance from cementoenamel junction to the incisal edge. ${ }^{6}$ It has been suggested that a talon cusp might occur as a result of an outward folding of the inner epithelial cells and transient focal hyperplasia of the mesenchymal dental papilla. It has also been proposed that the talon cusp results from failed separation of a group of hyperactive cells that proliferate from the primordial cells. The hyperactivity of the primordial cells is genetically determined, but the degree of hyperactivity is influenced by environmental factors. ${ }^{7}$ It has been suggested that improper actin between ectoderm and mesoderm during the odontogenesis process on epithelial bulging may be the etiological factors for the formation of talon cusp. ${ }^{8}$

The first reported case in primary dentition is by Sawyer et al in 1976, found in the archaeological remains of prehistoric times. Since then nearly 39 more case reports have been published, one of them being present in the archaeological remains of a five year old child in UK dating back to the period AD 950-1350. This first clinical case in the primary dentition was reported by Henderson in 1977 in a four year old Filipino girl. ${ }^{9}$ 
This abnormality has been more frequently reported in Asian population based on the clinical experience. Chen and Chen stated that, there does not appear to be a difference in the prevalence of talon cusp in the primary and permanent teeth in the Chinese population. This point is worth noting as its prevalence in primary dentition in the Indian population may also be more than reported. In the present case too, it had not been observed by the parent and had got noticed during a routine clinical examination. ${ }^{10}$

Radiographically the talon cusp is visible as a radiopaque structure. Most authors reported the talon cusp to be composed of normal enamel, dentin and pulp. Individuals with talon cusps on a deciduous maxillary later incisor showed a high proportion of odontogeneic abnormalities in the permanent successor. ${ }^{11}$ However in our case there was no abnormal finding seen in the permanent tooth buds. Small talon cusps are usually symptomatic and need no treatment. Large talon cusps may cause occlusal interference, irritation of the tongue during speech and mastication, displacement of the affected tooth, carious lesion in the developmental grooves delineating the cusp, pulp necrosis, periapical pathosis, attrition of opposing tooth and periodontal problems due to excessive occlusal forces. ${ }^{12}$

The treatment of a talon cusp is dependent upon whether the cusp contains a pulp horn or not. However radiographic view is inherently difficult in tracing pulpal configuration inside the talon cusp because the cusp is superimposed over the affected tooth crown. ${ }^{13}$

Early diagnosis and definitive treatment always necessary to prevent complications and simple prophylactic measures such as fissure sealant is done in the present case. However the management depend upon size, complications and patients compliance. ${ }^{14}$

\section{Conclusion:-}

Talon cusp is not an innocuous defect, as it may provide a substantial challenge during diagnosis and treatment planning. Role of Pediatric dentist is utmost important in early diagnosis to minimize or prevent complication and also recommended not only to improve aesthetics but also to restore the functional occlusion, prevent caries formation, and preserve the vitality of the affected tooth.

\section{References:-}

1. AI-Omari M.A.O, Hattab F. N, Darwazeh A. M. G. \& Dummer P. M. H. Clinical problems associated with unusual cases of talon cusp. Int Endod J 1999, 32, 183-190.

2. H. Cern Gungor, Nil Altay, and F. Figen Kaymaz, Ankara. Pulpal tissue in bilateral talon cusps of primary central incisors. Report of a case. Oral Surg Oral Med Oral Pathol Oral Radiol Endod 2000;89:231-5.

3. Hattab FN. Yassin OM. Al-Nimri KS. Talon cusp in permanent dentition associated with other dental anomalies: review of literature and report of seven cases. J Dent Child 1996; 63:368-76

4. J.K.Mellor and L.W.Ripa. "Talon cusp: a clinically significant anomaly," Oral Surgery, Oral Medicine, Oral Patholgy.1970,29, 225-228.

5. G.Lomacali, S.Hazar and H.Altinbulak. "Talon cusp: report of five cases," Quintessence International.1994,25, 431433.

6. J.K.Dash, P.K.Sahoo and S.N.Das. "Talon cuso associated with other dental anomalies: a case report," International Journal of Paediatric Dentistry.2004,14, 295-300.

7. P.J.Davis and A.H.Brook. "The presentation of talon cusp: diagnosis, clinical features, associations and possible eitiolgy,” British Dental Journal. 1986,160,84-88.

8. F.N.Hattab, O.M.Yassin and K.S.Al-Nimri. "Talon cusp clinical significance and management: case reports," Quintessence International. 1995,26,115-120.

9. C.K.Lee, N.M.King, E.C.M.Lo and S.Y.Cho. "The relationship between a primary maxillary incisor with a talon cusp and the permanent successor: a study of 57 cases," International Journal of Pediatric Dentistry.2007,17,178-185.

10. S.Sarkar and J.Misra. "Talon cusp in the deciduous dentition: a case report," Journal of the Indian Society of Pedododntics and Preventive Dentistyyry.2000,18,151-152.

11. J.J.Segura-Egea, A.Jimenez-Rubio, J.V.Rios-Santos and E.Velasco-Ortega,'Dens evanginatus of anterior teeth (talon cusp): report of five cases," Quintessence International.2003,34,272-277.

12. C.L.Mader and S.L.Kellogg. "Primary talon cusp," ASDC Journal of Dentistry for Children.1985,52,223-226.

13. Lin LM, Chance K, Skribner J,Langeland K. Dens evaginatus: a case report. Oral Surg Oral Med Oral Pathol Oral Radiol Endod 1987;63:86-89.

14. F.N.Hattab and O.M.Yassin. "Bilateral talon cusps on primary central incisors: a case report," International Journal of Pediatric Dentistry.1996,6,191-195. 